\title{
PEMBAYARAN GANTI RUGI BAGI KORBAN PEMERKOSAAN DALAM QANUN ACEH NOMOR 6 TAHUN 2014 (TINJAUAN PERSPEKTIF HAM INTERNASIONAL)
}

\author{
Nairazi AZ ${ }^{1}$, Aidil Fan ${ }^{2}$ \\ Dosen Tetap Fakultas Syariah Prodi Hukum Pidana Islam (Jinayah) \\ Institue Agama Islam Negeri Langsa \\ ${ }^{1}$ nairazi@iainlangsa.ac.id, ${ }^{2}$ aidilfan@iainlangsa.ac.id
}

\begin{abstract}
Rape victims suffer physical effects in the form of organ damage in the form of tearing of the hymen, sexually transmitted diseases, unwanted pregnancy, and victims are also vulnerable to severe trauma. Compensation for rape victims in Aceh Qanun No. 6 of 2014 concerning Jinayat Law contained in Article 51 which the maximum amount of restitution uqubat is 750 grams of gold. For the implementation of the rape fingerprint case which was decided by the Langsa City Court of Langsa in 2016, no restitution was given, because the victim's request regarding a reimbursement was not stated in the prosecutor's lawsuit, and the victim also did not demand a repeat claim regarding restitution. Whereas for compensation there were no detailed rules governing this at the time, especially the institution authorized to pay the compensation was Baitul Mal Kota. In International Human Rights itself mentions the importance of compensation given to victims, and victims' families if the victims become the backbone of the family, and experience disabilities, in the form of restitution, compensation and other assistance as outlined in state legislation, this is stated in in the "Declaration of Basic Principles of J ustice for Victims of Crime and Abuse of Power" in Milan In 1985, because the previous declaration on criminal offenses only prioritized the human punishment given to the perpetrators, while the rights of victims were ignored. If seen from the juridical point of view about the uqubat ta'zir jarimah rape, especially regarding compensation which has been in accordance with international human rights, namely the juridical aspect of Aceh Qanun No. 6 of 2014 does not neglect the rights of rape victims.
\end{abstract}

Keywords: Compensation Payment, Rape Victim, Qanun Aceh No. 6 of 2014, International Human Rights Perspective

Abstrak, Korban pemerkosaan mengalami dampak fisik berupa kerusakan organ tubuh berupa robeknya selaput dara, terkena penyakit menular seksual, kehamilah yang tidak dikehendaki, dan korban juga rentan mengalami trauma yang cukup parah. Ganti rugi bagi korban pemerkosaan dalam Qanun Aceh No. 6 Tahun 2014 Tentang Hukum Jinayat tertuang dalam Pasal 51 yang besaran uqubat restitusi maksimal 750 gram emas. Untuk implementasi kasus jarimah pemerkosaan yang diputuskan oleh Mahkamah Syar'iyah Kota Langsa pada Tahun 2016 tidak diberikannya restitusi, karena permintaan korban mengenai resitusi tidak dituangkan di dalam gugatan kejaksaan, dan korban juga tidak menuntut ulang gugatan mengenai restitusi. Sedangkan untuk kompensasi belum adanya aturan terperinci yang mengatur tentang hal tersebut pada saat itu, terutama lembaga yang berwenang untuk membayar kompensasi tersebut yaitu Baitul Mal Kota. Di dalam HAM Internasional sendiri menyebutkan pentingnya ganti rugi yang diberikan kepada korban, maupun keluarga korban jika korban menjadi tulang punggung keluarga, dan mengalami kecacatan, baik berbentuk restitusi, kompensasi maupun 
bantuan-bantuan lain yang dituangkan di dalam perundang-undangan Negara, ini tertuang di dalam "Declaration of Basic Principles of J ustice for Victims of Crime and Abuse of Power" di Milan Pada Tahun 1985, karena deklarasi sebelumnya mengenai tindak pidana hanya memprioritaskan sisi hukuman manusiawi yang diberikan kepada pelaku, sedangkan hak-hak korban terabaikan. Jika dilihat dari sisi yuridis mengenai uqubat ta'zir jarimah pemerkosaan, terutama mengenai ganti rugi telah berkesesuain dengan HAM Internasional, yaitu aspek yuridis Qanun Aceh No. 6 Tahun 2014 tidak mengabaikan hak-hak korban pemerkosaan.

Kata Kunci: Pembayaran Ganti Rugi, Korban Pemerkosaan, Qanun Aceh No. 6 Tahun 2014, Perspektif HAM Internasional

\section{Pendahuluan}

Mengenai kasus pemerkosaan merupakan prilaku yang sangat menyimpang dilakukan oleh manusia yang sudah melewati batas-batas kemanusiaannya, bahkan melebihi sisi binatang sekalipun. Adapun dampak sosial yang dialami oleh korban pemerkosaan yaitu berdampak terhadap fisik dan jiwa yang begitu serius. Akibat yang ditimbulkan dari korban berupa fisik adalah: (1) mengalami kerusakan organ fisik berupa pingsan dan rusaknya selaput dara; (2) memungkinkan terkena penyakit yang menular kepada korban berupa penyakit seksual; (3) terjadinya kehamilan yang tidak diinginkan. Dan korban juga rentan terhadap trauma yang begitu panjang disertai dengan dampakdampak psikologis yang lain. Ada pula yang merasa terbatasi di dalam berhubungan dengan orang lain, baik itu berhubungan sekual yang disertai dengan ketakutan akan munculnya kehamilan akibat dari perkosaan. Bagi korban pemerkosaan akan mengalami trauma psikologis yang sangat hebat dan kemungkinan akan merasakan dorongan yang kuat untuk bunuh diri. ${ }^{1}$

Dalam kasus pemerkosaan pihak yang paling dirugikan adalah korban yang seharusnya mendapatkan perlindungan hukum, salah satunya adalah bentuk pembayaran ganti-kerugian dari peristiwa yang dialaminya berupa biaya perobatan baik bersifat jasmani maupun rohani ataupun untuk keluarganya, jika ia mengalami trauma yang cukup panjang, dan ia sendiri merupakan tulang punggung keluarga. Dalam Islam telah diatur mengenai perlindungan hukum terhadap korban tindak pidana yaitu berbentuk ganti kerugian (diyat). Dan diyat adalah hukuman pokok untuk tindak pidana pembunuhan dan penganiayaan baik sengaja dan tidak sengaja (khata'). Meskipun bersifat hukuman, namun harta yang diberikan untuk korban atau keluarganya, bukan untuk perbendaharaan Negara. $^{2}$

Imam Syafi'I juga menyatakan hukuman terhadap pelaku pemerkosaan selain kewajiban membayar mahar, juga mendapatkan sanksi hadd zina. Pendapat ini juga dinyatakan oleh Imam al-Laits, dan diriwayatkan oleh Sayyidina Ali bin Abi Thalib menyatakan hal yang sama. Bahwa hadd zina merupakan hak Allah (haqqullah),

${ }^{1}$ Faturochman, Ekandari Sulistyaningsihlm., Dampak Sosial Psikologis Perkosaan, Buletin Psikologi, Tahun X, No. 1, Juni 2002, hlm. 8-10

${ }^{2}$ Muslich, Ahamd Wardi., Pangantar dan Asas Hukum Pidana Islam, (Jakarta: Sinar Grafika , 2006) hlm. 155 
sedangkan mahar adalah hak manusia (Haqqun Adam). Dalam hal ini, kedua-duanya boleh dikumpulkan dalam satu hukuman, sebagaimana orang yang mencuri, selain dikenai sanksi potong tangan (hadd shariqah) yang merupakan (Haqqullah), juga diwajibkan mengembalikan harta yang dicuri yang merupakan (Haqqul Adami). ${ }^{3}$

Dalam dimensi Hukum Pidana Islam, seluruh pihak berkaitan dengan perbuatan tindak pidana akan dilindungi hak-haknya, berupa perlindungan hukum bagi korban, khususnya perkosaan yang dibuktikan dengan adanya hukuman tambahan yang dibebankan kepada pelaku perkosaan berupa pemberian ganti kerugian atau dalam literatur fiqh dikenal at-ta'wid dalam bentuk as-shadaq kepada pihak korban. ${ }^{4}$ Setiap lakilaki yang memperkosa wanita dalam kategori apa saja baik yang belum menikah maupun janda, diharuskankan untuk membayar ganti rugi berupa mahar mitsil. Jika dilihat dalam konteks keindonesiaan, maka jumlah mahar seperti yang termaktub di dalam KHI Pasal 30 dan 31 .

Untuk masalah pembayaran ganti rugi bagi korban, Islam mengatur secara terperinci baik itu di dalam al-Quran maupun hadits yaitu pembayaran ganti rugi bagi korban pembunuhan. Jika ditelusuri lebih mendalam, korban pemerkosaan sama seperti korban pembunuhan, karena bagaimanapun korban pemerkosaan telah dibunuh secara psikologis yang rentan mengalami kegilaan dan bunuh diri.

Qanun Aceh No. 6 Tahun 2014 Tentang Hukum Jinayat berbicara aspek legalitas mengenai ganti kerugian bagi korban pemerkosaan yang tertuang di dalam Pasal 51 yang berbunyi:

(1) Dalam hal ada permintaan korban, setiap orang yang dikenakan 'uqubat sebagaimana dimaksud dalam pasal 48 dan pasal 49 dapat dikenakan 'uqubat restitusi paling banyak 750 (tujuh ratus lim puluh) gram emas murni.

(2) Hakim dalam menetapkan besaran 'uqubat restitusi sebagaimana dimaksud pada ayat (1) perlu mempertimbangkan kemampuan keuangan terhukum.

(3) Dalam hal jarimah sebagaimana dimaksud pada ayat (1) dilakukan karena terpaksa oleh sesuatu kekuasaan yang tidak dapat dihindari, maka 'uqubat restitusi untuk korban dibebankan kepada yang memaksa dan pelaku. ${ }^{5}$

Sementara aturan kompensasi tidak diatur di dalam qanun jinayat Aceh, terkecuali mengenai salah tangkap dan orang yang ditahan setelah itu diputuskan bebas oleh Mahkamah Syar'iyyah, dan ini termaktub pada pasal 68 dalam Qanun Aceh No. 6 Tahun 2014.

Dan untuk kasus pemerkosaan yang terjadi di Kota Langsa, Mahkamah Syar'iyyah yang berwenang untuk mengadili kasus pemerkosaan terjadi sebanyak satu kali yaitu pada Tahun 2016, putusan yang diputuskan tanpa pembayaran ganti rugi yang diterima oleh korban baik berbentuk restitusi maupun kompensasi. Putusan yang dihasilkan hanya

${ }^{3}$ Lihat, al-Muntaqa Syarah al-Muwatha', Juz V/268-269

${ }^{4}$ al-Jazaziri, Abdurrahman., Kitab al-Fiqh 'ala Mazhahib al-Arba'ah, (Beirut: Dar al-Fikr, tt), Juz V, hlm. 73

${ }^{5}$ Qanun Aceh No. 6 Tahun 2014 Tentang Hukum Jinayat 
hukuman berbentuk penjara kepada pelaku sama seperti halnya dengan hukuman yang terdapat di dalam KUHP Pasal 285.

Sedangkan untuk di Indonesia sendiri, mengenai aturan restitusi maupun kompensasi bagi korban pemerkosaan tidak diatur secara terperinci melainkan hanya diatur di dalam Pasal 14c KUHP yaitu ganti rugi dalam KUHP syarat seseorang untuk tidak menjalani pidana. Syarat/pengganti untuk menghindari atau tidak menjalani pidana, dan konsep ini berorientasi pada pelaku bukan kepada korban.

Adapun Pasal 14c KUHP berbunyi:

(1) Dalam perintah yang tersebut pada pasal 14a, kecuali dalam hal dijatuhkan hukuman denda, maka bersama-sama dengan perjanjian umum bahwa siterhukum tidak akan melakukan perbuatan yang dapat dihukum, maka hakim boleh mengadakan perjanjian istimewa, bahwa siterhukum akan mengganti kerugian yang timbul karena perbuatan yang dapat dihukum itu, semuanya atau untuk sebagian saja yang ditentukan dalam tempo yang akan ditetapkan, yang kurang lamanya daripada tempo percobaan itu.

(2) Kalau ada alasannya, maka dalam perintahnya, hakim boleh mewajibkan kepada sebuah balai yang mempunyai hak badan hukum dan berkedudukan di Negara Indonesia, atau kepada orang yang memegang sebuah balai yang berkedudukan disitu, atau kepada seorang amtenar istimewa, supaya memberi pertolongan dan bantuan kepada siterhukum tentang menepati perjanjian istimewa itu.

(3) Perjanjian-perjanjian tidak boleh membatasi kemerdekaan agama dan politik.

Untuk implementasi aturan ganti rugi bagi korban pemerkosaan secara mayoritas ditujukan pada kaum perempuan dan anak-anak yang dalam pandangan berbagai pihak merupakan pihak yang lemah, perlu mendapat perlindungan yang pantas dan layak. Hal ini disebabkan karena tidak sedikit kasus kejahatan yang menyebabkan perempuan menjadi korban kejahatan terutama dalam kasus kekerasan seksual atau yang lebih sering dikenal dengan perkosaan.

Adapun HAM internasional sendiri pada saat ini sangat memprioritaskan mengenai perlakuan terhadap korban, yang mana generasi HAM sebelumnya lebih memfokuskan pada perlindungan pelaku tindak pidana. Sedangkan perhatian terhadap korban yang seharusnya dilakukan atas dasar belas kasihan dan hormat atas martabat korban seolaholah dilupakan atau paling tidak kurang diperhatikan. ${ }^{6}$

Pada tahun 1985 melalui Declaration of Basic Principles of Justice for Victims of Crime and Abuse of Power, perhatian PBB mulai meningkat khususnya yang berkaitan dengan akses untuk memperoleh keadilan, hak untuk memperoleh kompensasi, restitusi dan bantuan-bantuan lain yang harus diatur dalam undang-undang Nasional. Bahkan kompensasi maupun restitusi juga berlaku bagi keluarganya, khususnya yang hidupnya

${ }^{6}$ Zaki Ulya, Dinamika Penerapan Hukum Jinayat Sebagai Wujud Rekonstruksi Syari'at Islam Di Aceh, Jurnal Rechtsvinding, Vol. 5 No. 1, 2016, hlm. 139 
tergantung pada korban yang mati atau cacat, termasuk juga korban penyalahgunaan kekuasaan (Victims of Abuse of Power). ${ }^{7}$

Untuk negara Indonesia sendiri khususnya mengenai pelanggaran HAM dibentuk pengadilan HAM berdasarkan Keputusan Presiden No. 31 Tahun 2001 tentang pembentukan Pengadilan HAM pada Pengadilan Negeri Jakarta, Surabaya, Medan dan Makassar sebagai pelaksana dari pasal 45. Dan Pengadilan HAM yang ada di Indonesia hanya memfokuskan pada pelanggaran HAM yang berat yaitu berdampak secara luas baik pada tingkat nasional maupun internasional ${ }^{8}$ dengan mengabaikan pelanggaran HAM bagi korban pelanggaran pidana secara indivual, khususnya korban pemerkosaan yang terdapat di dalam KUHP juga diatur dalam HAM Internasional pada tahun 1985.

\section{Metode Penelitian}

Adapun metode penelitian yang digunakan dalam mengkaji permasalahan ini yaitu metode yuridis normatif, dengan pendekatan keputstakaan. Adapun Data yang dipergunakan adalah data sekunder yang mencakup bahan hukum primer, bahan hukum sekunder, dan bahan hukum tersier. Keseluruhan bahan tersebut diperoleh dari kepustakaan dengan menelusuri buku-buku teks terkait, peraturan perundang-undangan dan sumber lainnya. Seluruh data dan bahan yang telah dikumpulkan akan dianalisis secara deskriptif.

\section{Ganti Rugi Bagi Korban Pemerkosaan Dalam Hukum Pidana Islam}

Adapun dalil al-Quran yang membahas korban pemerkosaan adalah surat al An'am: 145. ${ }^{9}$ Ibn Qayyim mengisahkan ayat ini dijadikan hujjah oleh Ali bin Abi Thalib RA di hadapan khalifah Umaf bin Khattab RA untuk membebaskan seorang perempuan yang dipaksa berzina oleh seorang pengembala, demi mendapatkan air minum karena perempuan tersebut sangat kehausan. ${ }^{10}$

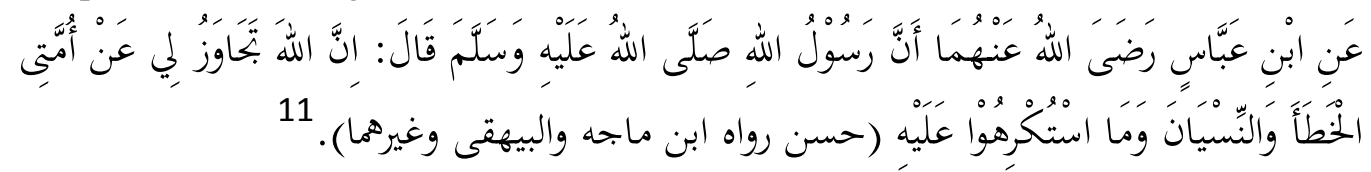

Jika seorang wanita disetubuhi secara paksa, maka tidak ada hukuman hadd baginya, sebagaimana yang tertulis pada ayat di atas "barangsiapa terpaksa bukan karena

\footnotetext{
${ }^{7}$ Muladi, Hak Asasi Manusia: Hakekat, Konsep dan Implikasinya dalam Perspektif Hukum dan Masyarakat, Cet. III, (Bandung: PT. Refika Aditama, 2009), hlm. 107

${ }^{8}$ R. Wilyono, Pengadilan Hak Asasi Manusia di Indonesia, Cet. III, (Jakarta: Kencana, 2015), hlm. 14

${ }^{9}$ QS. al-An'am: 145 (Lihat Quran kemenag.go.id)

${ }^{10}$ Abdul Qadir Audah, al-Taysri' al-J ina'l al-Islami, Juz II hal. 365, Wahbah Zuhaili, alFiqh al-Islami wa Adillatuhu, Juz VII, hal. 294

${ }^{11}$ Bukhari no.7352, Muslim no.1716, Ahmad (IV/198), Abu Daud no.3574, Ibn Majah no. 2314 dan Baihaqi (X/118-119)
} 
menginginkannya dan tidak pula melampaui batas, maka tidak ada dosa baginya". Satu ulamapun tidak terjadi perselisihan di dalamnya, akan tetapi terjadi pebedaan mengenai konteks wajibnya pembayaran ganti rugi berupa mahar bagi korban pemerkosaan, Imam Malik dan Imam Syafi'i berijtihad wajib diberikan mahar kepada korban, sementara Imam Abu Hanifah berijtihad tidak wajib bagi pelaku memberikan ganti rugi kepada korban pemerkosaan. ${ }^{12}$

Dalam dimensi Hukum Pidana Islam, seluruh pihak berkaitan dengan perbuatan tindakan pidana akan dilindungi hak-haknya, perlindungan hukum terhadap korban tindak pidana, khususnya perkosaan dibuktikan dengan adanya hukuman tambahan yang dibebankan kepada pelaku perkosaan berupa pemberian ganti kerugian atau dalam literatur fiqh dikenal at-ta'wid dalam bentuk as-shadaq kepada pihak korban. ${ }^{13}$

Imam Syafi'I juga menyatakan hukuman terhadap pelaku pemerkosaan selain kewajiban membayar mahar, juga mendapatkan sanksi hadd zina. Pendapat ini juga dinyatakan oleh Imam al-Laits, dan diriwayatkan oleh Sayyidina Ali bin Abi Thalib juga menyatakan hal yang sama. Bahwa hadd zina merupakan hak Allah (haqqullah), sedangkan mahar adalah hak manusia (Haqqun Adam). Dalam hal ini, kedua-duanya boleh dikumpulkan dalam satu hukuman, sebagaimana orang yang mencuri, selain dikenai sank potong tangan (hadd shariqah) yang merupakan (Haqqullah), juga diwajibkan mengembalikan harta yang dicuri yang merupakan (Haqqun Adami). ${ }^{14}$

Laki-laki yang melakukan perbuatan asusila kepada wanita berupa pemerkosaan baik yang belum menikah maupun janda diharuskan membayar mahar mitsil. Jika dikaitkan dengan konteks keindonesiaan, maka jumlah mahar yang harus dibayarkan seperti yang tertuang dalam pasal 30 dan 31 dalam KHI. Jika ditinjau dalam konteks hadits yang disandarkan kepada Siti Aisyah R.A mengenai mahar yang diberikan Rasulullah SAW kepada isterinya sebesar 12.5 uqyah. $^{15}$ Agak kurang relevan dikarenakan jumlah mahar yang disebutkan di dalam KHI tidak diperjelasan secara rinci, karena bagaimanapun mengenai jumlah dalam bahasa hukum tidak boleh menggunakan bahasa "ambiguitas" yaitu tanpa ukuran maksimal maupun minimal.

Di dalam Islam, apabila pelaku maupun keluarga pelaku tidak sanggup dalam pembayaran restitusi, maka lembaga Negara yang mengambil alih dalam pembayaran kompensasi yaitu lembaga baitul mal, dengan jumlah yang dianalogikan kepada mahar yang diberikan Rasulullah SAW kepada isterinya yaitu sebesar minimal 500 dirham dan maksimal 4000 dirham atau 400 dinar.

\footnotetext{
${ }^{12}$ Sayyid Sabiq, Ringkasan Fiqh Sunnah,(Beirut: Beirut Publishing, tt) hal. 578
}

${ }^{13}$ Abdurrahman al-Jazaziri, Kitab al-Fiqh 'ala Mazhahib al-Arba'ah, Beirut: Dar al-Fikr, tt, Juz V, hal. 73

${ }^{14}$ Lihat, al-Muntaqa Syarah al-Muwatha', Juz V/268-269

${ }^{15}$ Uqyah: harga satu uqyah seharga 40 dirham atau 50 dirham. Maka 12,5 uqyah sekitar 500 dirham atau 625 dirham, harga 1 dirham setara 2,975 gram perak murni. Jadi, 500 dirham adalah 1.487,5 gram perak murni, bila dikonversi ke rupiah saat ini, jika harga 1 gram perak murni Rp. 95.000 maka 1.487,5 gram perak murni senilai Rp. 141.312.500 
Sementara ganti rugi menurut yang diberikan kepada korban pemerkosaan menurut pendapat fuqaha dalam kitab Fiqh Ala Madzahibul Arba'ah yaitu: apabila seorang lakilaki memaksa perempuan untuk melakukan zina maka wajib bagi perempuan itu menerima mahar yang sesuai baik itu perempuan merdeka atau budak. ${ }^{16}$

Mengenai korban wajib diberikan ganti rugi berupa mahar dan apabila perkosaan itu dilakukan dengan penganiayaan maka korban berhak mendapatkan diyat. Besarnya ganti-rugi yang diterima oleh korban ditentukan oleh hakim melalui konsep hukumah al'adl.

Korban asusila maupun yang mengalami kecanduan pada konten-konten pornografi seharusnya dilakukan upaya-upaya rehabilitasi untuk memulihkan keguncangan psikologis yang dialami oleh korban. Dan juga pembayaran ganti rugi baik berbentuk restitusi ataupun kompensasi (diyat) yang mekanisme pembayarannya diputuskan melalui putusan pengadilan yang sudah inkrah, baik yang diberikan kepada korban maupun kepada keluarga korban, jika korban sebagai tulang punggung keluarga karena bagaimanapun pembayaran ganti rugi baik restitusi maupun kompensasi bertujuan untuk melindungi hak-hak hidup korban dan kelurganya.

Pembayaran ganti rugi (diyat) terutama berntuk kompensasi dalam tindak pidana pembunuhan maupun pencideraan, yang mana korban dan kelurganya memberikan pemaafan kepada pelaku, akan tetapi pelaku dan ahli waris tidak menyanggupi dalam pembayaran ganti rugi (restitusi), maka Negara mengambil alih dalam pembayaran ganti rugi (kompensasi) melalui lembaga baitul mal yang bertujuan untuk menyejahterakan umat Islam. ${ }^{17}$

Pada masa pemerintahan Umar bin Khattab, salah satu aspek pengeluaran keuangan baitul mal yaitu menjamin kesejahteraan kepada wanita yang ditinggal mati syahid keluarganya. Seperti yang dialami al-Khansa yang ditinggal empat orang putranya yang gugur di medan perang al-Qadisiyah. Kepada al-Khansa diberikan tunjangan untuk keempat putranya sebesar 200 dirham untuk setiap anak setiap bulan hingga al-Khansa wafat. $^{18}$

Begitu juga masa kepemimpinan Umar bin Khattab membentuk Departemen Jaminan Sosial yang pendistribusiannya melalui baitu mal untuk membantu kalangankalangan seperti fakir miskin dan orang-orang yang menderita, sehingga mereka memperoleh penghidupan sendiri yang diberikan bantuan keuangan secara tahunan dari baitu mal. ${ }^{19}$

Ketika Umar membagikan harta fai' kepada kaum muslimin, tiba-tiba ia melihat di wajah salah seorang dari mereka terdapat bekas luka yang ternyata luka akibat pertempuran di medan perang. Kemudian Umar menambahkan lagi padanya seribu

\footnotetext{
${ }^{16}$ Abdur Rahman al-Jaziri, Kitabul Ala Madzahibul Arba'ah, (Beirut: tt, )Juz II, hal. 73

${ }^{17}$ Neng Djubaedah, Pornografi dan Pornoaksi Ditinjau dari Hukum Islam, (Jakarta, Kencana 2009), hlm. 300

${ }^{18}$ Ash-Shalabi, The Great Leader of Umar bin Khattab, terj. Khoirul Amru Harahap dan Akhmad Faozan, (Jakarta: Pustaka al-Kautsar, 2008), hlm. 209

${ }^{19}$ Fazlur Rahman, Doktrin Ekonomi Islam, dengan judul asli "Economic Doctrines of Islam", Jilid I, (Yogyakarta: PT. Dana Bhakti Wakaf, 1995), hlm. 172
} 
dirham. Kemudian umar memberikan seribu dirham lagi kepada orang itu. Demikian seterusnya umar menambah seribu dirham hingga lelaki itu pergi. Hal demikian Umar lakukan sebagai ganti atas luka di wajahnya. ${ }^{20}$

Di dalam hukum Islam sendiri tidak terjadi pemisahan secara mutlak mengenai hukum publik dan privat, tertutama mengenai aturan pembayaran diyat sebagai bentuk pelindungan yang diberikan kepada individu, keluarga maupun masyarakat. Sedangkan aturan rehabilitasi selain diprioritaskan kepada korban, juga diperuntukkan kepada pelaku khususnya pelaku yang dilakukan oleh anak-anak di bawah umur dikarenakan faktor yang paling dominan dialami oleh pelaku adalah faktor kelalaian dari pihak keluarga dan masyarakat.

Jika ditinjau pendapat Imam Syafi'i R.A yang menganalogikan ganti rugi kasus pemerkosaan berupa mahar dengan konteks hukum ke kinian, justru terjadi pertentangan dikarenakan dalam hukum ke kinian bentuk ganti rugi berupa nominal haruslah dalam ukuran yang jelas dan bahasa yang digunakan tegas dan terperinci, serta tidak mengandung makna yang ambiguitas. Sedangkan pendapat yang mengatakan bahwa ukuran ganti rugi dengan menganalogikan mahar yang diberikan oleh Rasulullah SAW kepada isteri-isterinya, dan ini butuh kajian-kajian yang lebih lanjut.

Untuk qiyas sendiri merupakan perluasan ketentuan hukum yang terdapat pada asal kasus baru yang terjadi. Penyamaan pada 'illat merupakan indikasi bahwa qiyas bukan merupakan pembentukan hukum, namun hanya sebagai penyingkap (mudhir) adanya persamaan sebab-sebab hukum. Hal ini sejalan dengan konsep hukum Islam sebagai yang bersifat ditemukan, bukan dibuat. Metode qiyas dalam hal ini merupakan generasi ketiga dari model penemuan hukum Islam, setelah metode mantiq nash dan mafhum nash gagal diperdayakan dalam menyingkap kasus hukum baru. ${ }^{21}$

Adapun qiyas dilihat dari segi kekuatan dibagi menjadi 3 macam yaitu:

1. Qiyas al-Aulawi: merupakan suatu illat hukum yang diberikan pada ashal lebih kuat diberikan pada furu

2. Qiyas al-Musawi: yaitu suatu qiyas yang illatnya mewajibkan hukum, ataupun mengqiyaskan sesuatu yang lain yang keduanya bersamaan dalam keputusan menerima hukum tersebut.

3. Qiyas al-Adna: yaitu mengqiyaskan sesuatu yang kurang kuat menerima hukum yang diberikan pada sesuatu yang memang patut menerima hukum tersebut.

Untuk tindak pidana pemerkosaan sendiri merupakan suatu tindakan yang dapat membunuh korban dari segi kejiwaan, jika tidak ditangani secara tepat maka korban rentan akan melakukan bunuh diri. Jika dilihat dari segi illat maka tindak pemerkosaan dapat dipersamakan dengan tindakan pembunuhan yang termasuk pada kategori "qiyas al-musawi". Dan untuk hukum modern ke kinian menuntut bahwa hukum harus bersifat tegas, jelas dan terperinci tanpa mengandung makna ambiguitas. Jelas dalam ganti rugi

\footnotetext{
${ }^{20}$ Jaribah al-Haritsi, Fikih Ekonomi Umar ibnu al-Khattab, terj. Asmuni Sholihin Zamakhsyari, (Jakarta: Khalifa Grup Pustaka al-Kaustar, 2010), hlm. 367

21 Maizul Imran, Qiyas dan Analogi Hukum (Suatu Telaah dan Perbandingan dalam Penemuan Hukum), Alhurriyah: Jurnal Hukum Islam, Vol. 02 No. 01 Edisi Januari-Juni, 2017, hlm. 101
} 
pembunuhan dalam sistem hukum pidana Islam bersifat terperinci sebagaimana yang dijelaskan di dalam al-Quran dan Hadits, yang seharusnya ganti rugi pemerkosaan sama seperti ganti rugi yang diberikan kepada korban pembunuhan.

\section{Ganti Rugi Dalam Qanun Aceh Nomor. 6 Tahun 2014 Tentang Hukum Jinayat}

Mengenai ganti rugi yang terdapat di dalam Qanun Aceh No. 6 Tahun 2014 Tentang Hukum Jinayat yaitu:

Pasal 51 yang berbunyi:

(1) Dalam hal ada permintaan korban, setiap orang yang dikenakan 'uqubat sebagaimana dimaksud dalam pasal 48 dan pasal 49 dapat dikenakan 'uqubat restitusi paling banyak 750 (tujuh ratus lim puluh) gram emas murni.

(2) Hakim dalam menetapkan besaran 'uqubat restitusi sebagaimana dimaksud pada ayat (1) perlu mempertimbangkan kemampuan keuangan terhukum.

(3) Dalam hal jarimah sebagaimana dimaksud pada ayat (1) dilakukan karena terpaksa oleh sesuatu kekuasaan yang tidak dapat dihindari, maka 'uqubat restitusi untuk korban dibebankan kepada yang memaksa dan pelaku. ${ }^{22}$

Pasal 68 berbunyi:

(1) Setiap orang yang ditangkap dan ditahan oleh aparat berwenang yang diduga melakukan jarimah tanpa melalui prosedur atau proses hukum atau kesalahan dalam penerapan hukum atau kekeliruan mengenai orangnya, berhak mendapatkan ganti kerugian

(2) Setiap orang yang ditahan dan setelah itu diputus bebas oleh mahkamah, berhak mendapatkan ganti kerugian

(3) Ganti kerugian sebagaimana dimaksud pada ayat (1) dan ayat (2) untuk satu hari ditetapkan sebesar 0,3 (nol koma tiga) gram emas murni atau uang yang nilainya setara dengan itu.

(4) Ketentuan lebih lanjut mengenai ganti kerugian sebagaimana pada ayat (3) diatur dalam Peraturan Gubernur.

Apabila terdakwa dijatuhi uqubat kompensasi sebagaimana yang dimaksud dalam Pasal 249 Qanun Hukum Acara Jinayah (QHAJ), maka pelaksanaan eksekusi dilakukan dengan tahapan-tahapan sebagai berikut:

a. Jaksa sebagai eksekutor (pelaksana) uqubat kompensasi.

b. Jaksa mengeluarkan surat pemberitahuan kepada terhukum untuk membayar dan menyerahkan uang kompensasi tersebut kepada korban atau kuasanya;

c. Penyerahan uang kompensasi dilakukan di hadapan Jaksa dengan membuat dan menandatangani berita acara penyerahan uang kompensasi tersebut.

\footnotetext{
${ }^{22}$ Qanun Aceh No. 6 Tahun 2014 Tentang Hukum Jinayat
} 
d. Pelaksanaan uqubat kompensasi harus sudah selesai dalam waktu satu bulan setelah putusan mahkamah memiliki kekuatan hukum tetap, apabila terhukum tidak membayarkannya setelah satu bulan, maka jaksa dapat menyita harta kekayaan terhukum.

Dalam putusan jinayah juga dilakukan penetapan apabila barang bukti diambil oleh Negara, dan bukti tersebut tidak terkait dengan perkara lain, maka dilakukan penguasaan oleh jaksa kepada kantor peleangan Negara untuk dilelang dalam waktu 3 bulan, yang mana hasilnya masuk kedalam kas Negara pengatasnamaan Jaksa sebagaimana yang tertuang dalam pasal 273 (3) KUHAP.

Sedangkan mengenai konteks biaya perkara dan ganti rugi yang dilakukan lebih seorang terpidana, maka pihak pengadilan akan menjatuhkan putusan pembayaran tersebut kepada siterpidana secara bersama-sama dan berimbang sebagaimana yang termaktub dalam pasal 275 KUHAP. Selain perampasan barang bukti dapat juga diputuskan untuk dimusnahkan atau dirusakkan sampai tidak dapat digunakan lagi (Pasal 52 (1) QHAJ).

Mengenai pelaksanaan putusan jinayah diyat (denda), QHAJ hanya mengatur dalam satu pasal saja, yaitu Pasal 250:

a. Jaksa sebagai pelaksana uqubat denda.

b. Jaksa dengan mengeluarkan surat pemberitahuan kepada terhukum untuk menyetor denda kepada Baitul Mal Kabupaten/Kota setempat.

c. Pelaksanaan uqubat denda dinyatakan selesai setelah terhukum menyerahkan tanda bukti penyetoran (penerimaan) uang denda yang dikeluarkan oleh baitul mal kepada jaksa.

d. Selanjutnya jaksa mengeluarkan surat pernyataan bahwa hukuman denda sudah dilaksanakan.

e. Apabila terhukum tidak membayarkannya setelah waktu satu bulan putusan berkekuatan hukum tetap, maka jaksa dapat menyita harta kekayaan terhukum. Kecuali apabila ada alasan yang mendesak, maka jaksa dapat memberi kesempatan menunda pembayaran dengan satu bulan lagi. Akan tetapi, untuk pemberian waktu pembayaran denda tidak dimungkinkan pada putusan pidana dalam acara pemeriksaan cepat karena dalam putusan acara cepat pembayarannya harus segera dilunasi. Apabila terhukum tetap tidak dapat membayarnya, maka jaksa dapat menyita harta kekayaan terhukum sesuai ketentuan dalam Pasal 250 ayat $3 .^{23}$

Untuk Qanun Hukum Acara Jinayat (QHAJ) menyebutkan mengenai ganti kerugian yang terdapat di dalam Qanun Aceh No. 6 Tahun 2014 Tentang Hukum Jinayat sebagaimana berikut:

Ganti kerugian dan rehabilitas di dalam QHAJ di mana sebelumnya, pengaturan tentang ganti kerugian dan rehabilitasi tidak pernah muncul, baik di dalam IR maupun HIR. Gagasan pengaturan tentang ganti kerugian dan rehabilitasi, sebetulnya bukan

${ }^{23}$ Zulkarnain Lubis dan Bakti Ritonga, Dasar-Dasar Hukum Acara Jinayah, Edisi I, (Jakarta: Prenadamedia Group, 2016), hlm. 166-168 
pemikiran orisinal yang ada di dalam Hukum Acara Jinayah, namun di dalam undangundang yang lebih dahulu sudah ada, dalam hal ini adalah Undang-Undang Pokok Kekuasaan Kehakiman Tahun 1964. Akan tetapi, pengaturan tentang ganti kerugian dan rehabilitasi tidak memiliki peraturan pelaksanaannya, sehingga proses pengajuan ganti kerugian dan rehabilitasi masih terhambat.

Ganti kerugian dan rehabilitasi diatur dalam Pasal 97 sampai dengan 100 Qanun Hukum Acara Jinayah. Pasal 97 menyatakan bahwa:

"Tersangka, Terdakwa atau Terpidana berhak menuntut ganti kerugian karena ditangkap, ditahan, dituntut dan diadili atau dikenakan tindakan lain tanpa alasan yang berdasarkan Qanun dan Peraturan Perundang-undangan lainnya atau karena kekeliruan mengenai orangnya atau hukum yang diterapkan"

Pengertian rehabilitasi tertuang di dalam KUHAP Pasal 1 butir 23. Rehabilitasi adalah hak seseorang untuk mendapat pemulihan haknya dalam kemampuan, kedudukan dan harkat serta martabatnya yang diberikan pada tingkat penyidikan, penuntutan atau peradilan karena ditangkap, ditahan, dituntut, ataupun diadili tanpa alasan yang berdasarkan undang-undang atau karena kekeliruan mengenai orangnya atau hukum yang diterapkan menurut cara yang diatur dalam undang-undang ini.

Senada dengan definisi tersebut, Pasal 99 Qanun Hukum Acara Jinayah menyatakan bahwa seseorang berhak memperoleh rehabilitas apabila oleh mahkamah diputus bebas atau diputus lepas dari segala tuntutan hukum yang putusannya telah mempunyai kekuatan hukum tetap. ${ }^{24}$

Berdasarkan ketentuan Qanun Hukum Acara Jinayah Pasal 89 ditetapkan bahwa ganti kerugian karena kesalahan penangkapan atau penahanan, untuk satu hari ditetapkan sebesar 0,3 gram emas murni atau uang yang nilainya setara dengan itu. Adapun ganti kerugian akibat kesalahan penggeledahan atau penyitaan adalah sebesar kerusakan atas barang penggeledahan dan penyitaan tersebut. ${ }^{25}$ Yang menjadi landasan mengenai uqubat denda dan restitusi dalam Qanun Aceh No. 6 Tahun 2014 Tentang Hukum Jinayat yaitu buku-buku fiqh dan hadits yang menyatakan bahwa pada masa nabi diyat berat yaitu 100 (seratus) ekior unta dewasa dianggap sama dengan harga 1.000 (seribu) dinar emas, lebih kurang sama dengan 4.200 (empat ribu dua ratus) gram emas pada masa sekarang. Berdasarkan pendapat ini, uqubat mati dapat disamakan dengan denda sebesar 4.000 (empat ribu) gram emas dibulatkan. Dengan demikian setengah hukuman mati, yaitu hukuman cambuk seratus kali dapat disamakan dengan denda sebesar 2.000 (dua ribu) gram emas. Berdasarkan uraian di atas maka satu kali hukuman cambuk pada dasarnya dianggap sama dengan penjara satu bulan atau denda sebesar 20 (dua puluh) gram emas. ${ }^{26}$

Namun demikian dengan mempertimbangkan kondisi ekonomi masyarakat di Aceh, penetapan denda dengan menggunakan emas dalam jumlah yang relatif besar terasa sangat memberatkan. Oleh karena itu, besaran uqubat denda diturunkan jumlahnya

\footnotetext{
${ }^{24}$ Ibid, hlm. 29-30

${ }^{25}$ Ibid, hlm. 58

${ }^{26}$ Dinas Syariat Islam Aceh, Hukum Jinayat, hlm. 60
} 
hingga $50 \%$ (lima puluh persen) dari ketentuan asal. Dengan demikian ditetapkan kesetaraan baru 1 (satu) kali cambuk setara dengan 1 (satu) bulan penjara dan setara pula dengan 10 (sepuluh) gram emas. ${ }^{27}$

Untuk memudahkan, Ketua Mahkamah Syar'iyyah Aeh diberi kewenangan untuk menetapkan kesetaraan harga emas dengan uang rupiah secara berkala. Penetapan ini akan diubah dan disesuaikan setiap ada perbedaan dengan harga pasar. Ketua Mahkamah Syar'iyyah wajib melakukan penyesuaian apabila harga dalam penetapan telah berbeda dari sepuluh persen dengan harga di pasaran, baik lebih mahal ataupun lebih murah. ${ }^{28}$

Dalam penyusunan Qanun Aceh No. 6 Tahun 2016 Tentang Hukum Jinayat menjadi pertimbangan terhadap substansi yang ada seperti yang dirumuskan oleh para ahli, kewenangan penyusunan secara formal oleh undang-undang diserahkan kepada pemerintah Aceh dan DPRA, sedang secara substansial penulisan rancangannya dipersiapkan oleh para ulama dan para sarjana, serta pembahasannya di DPRA yang didampingi oleh para ulama, sarjana dan praktisi.

Mengenai ganti kerugian akibat salah tangkap tertera pada Pasal 82 dan 89 Qanun Aceh No. 7 Tahun 2013 Tentang Hukum Acara Jinayat. Ketentuan qanun ini bersifat konkrit dengan menyatakan jumlah yang pasti, hakim dalam memutuskan jumlah ganti rugi sudah dapat dikalikan 0,3 gram emas dengan jumlah hari korban dalam tahanan. Sedangkan kerugian berupa kerusakan barang atau lainnya yang disebabkan oleh perbuatan penggeledahan atau penyitaan diganti sebesar dengan jumlah kerusakan tersebut.

Ganti rugi kepada korban salah tangkap atau salah tahan merupakan pertimbangan kemasalahatan Pemerintah Aceh. Kemaslahatan ini lahir dari interaksi fiqh dengan Kitab Undang-Undang Hukum Acara Pidana (KUHAP). Dan ini senada dengan pendapat Prof. Syahrizal Abbas dalam kata pengantar buku Hukum Jinayat dan Hukum Acara Jinayat yaitu "materi hukum jinayat dalam Qanun Aceh No. 6 Tahun 2014 dan materi hukum acara jinayat dalam Qanun Aceh No. 7 Tahun 2013 adalah hukum lahir dari ijtihad para ulama sekaligus hasil interaksi fiqh dan Kitab Undang-Undang Hukum Pidana (KUHP) dan Kitab Undang-Undang Hukum Acara Pidana (KUHAP). ${ }^{29}$

Ini merupakan ketentuan dasar tentang hak seorang korban pidana karena keliru atau salah mengenai tuduhan jarimah, sehingga menuntut ganti rugi kepada pengadilan yang mengadilinya. Hak menuntut ganti rugi tersebut dapat diajukan oleh korban yang bersangkutan atau oleh wali korban sebagaimana yang dimaksudkan pada Pasal 97 (2). Pada prosesnya, setelah melakukan penuntutan kepada Mahkamah yang mengadilinya, kemudian diperiksa dan diputuskan pada sidang Praperadilan.

Mengenai ganti kerugian dibebankan kepada pemerintah daerah. Biaya ganti rugi yang dimaksud merupakan tanggungjawab pemerintah yang menyelenggarakan sistem peradilan sebagai turunan dari lembaga yang mengawal jalannya undang-undang

\footnotetext{
${ }^{27}$ Ibid

${ }^{28}$ Penjelasan Qanun Hukum Jinayat

${ }^{29}$ Dinas Syariat Islam Aceh, Hukum Jinayat dan Hukum Acara Jinayat, (Banda Aceh: Naskah Aceh, 2015), hlm. iii
} 
(yudikatif). Biaya ganti rugi dibebankan kepada pemerintah melalui Anggaran Pendapatan dan Belanja Aceh (APBA) dan Anggaran Pendapatan dan Belanja Kabupaten/Kota. Aturan tentang biaya ganti kerugian ini diatur dalam Pasal 100 Qanun Hukum Acara Jinayat Aceh yang berbunyi: "Pembiayaan sebagaimana dimaksud dalam Pasal 99 dibebankan pada Anggaran Pendapatan dan Belanja Aceh dan Anggaran Pendapatan dan Belanja Kabupaten/Kota yang diatur lebih lanjut dalam Peraturan Gubernur". ${ }^{30}$

\section{Viktimologi Dalam Ham Internasional}

Dalam sejarah perkembangan HAM Internasional yaitu HAM yang lahir dipelopori oleh PBB ada 4 (empat) generasi sebagai berikut:

Generasi Pertama, lahir pada saat berakhirnya Perang Dunia II yaitu pengakuan prinsip kebebasan perseorangan yang secara substansial manusia membutuhkan keselarasan dan keserasian hidup yang berbekal pada pengakuan dimensi kemanusiaan secara objektif. Karena hak asasi manusia merupakan prasyarat yang harus ada dalam setiap kehidupan manusia untuk dapat hidup sesuai dengan fitrah kemanusiaannya. HAM generasi pertama hanya berbicara dalam aspek politik dan hukum, karena realitas yang terjadi pasca Perang Dunia II untuk menciptakan ketertiban hukum dan politik kepada negara-negara maju yang telah mendapat pengakuan dalam hak kemerdekaan.

Generasi Kedua, beranjak pada pemfokusan dalam bidang sosial, politik, ekonomi dan budaya. Yang perumusannya terjadi pada Sidang Umum PBB 16 Desember 1966, yakni International Covenant on Economic, Social and Cultural Rights dan International Covenant on Civil and Political Rights.

Generasi Ketiga, perkembangan pemikiran HAM yang mengalami peningkatan ke arah kesatupaduan antara hak-hak ekonomi, sosial, budaya, politik dan hukum dalam "satu keranjang" yang disebut dengan hak-hak melaksanakan pembangunan (the Rights of Development).

Generasi Keempat, kritik kepada peran negara yang begitu dominan dalam hal pembangunan ekonomi, dengan terabaiakannya aspek kesejahteraan rakyat, dan kritikan ini diprakarsasi oleh negara-negara di kawasan Asia pada tahun 1983 melahirkan deklarasi HAM yang dikenal dengan Declaration of the Basic Duties of Asia People and Geverment. $^{31}$

Untuk perlindungan hukum sendiri salah satunya tertuang dalam Pasal 3 Deklarasi Universal HAM PBB yang berbunyi "Setiap orang berhak atas penghidupan, kemerdekaan dan keselamatan". Begitu juga semangat HAM PBB untuk menghapus cara pandang dan sikap rasialis, memandang rendah yang lain, dan menilai manusia dari aspek agama, etnis, warna kulit, jenis kelamin, aliran politik dan asal usul keturunan yang

\footnotetext{
${ }^{30}$ Ibid, hlm. 142

31 Majda El-Muhtaj, Hak Asasi Manusia dalam Konstitusi Indonesia: Dari UUD 1945 Sampai Dengan Amendemen UUD 1945 Tahun 2002, Cet. II, (Jakarta: Kencana, 2007), hlm. 5355
} 
tertuang dalam pasal 1 dan 2 berbunyi: "Sekalian orang dilahirkan merdeka dan mempunyai martabat dan hak-hak yang sama", "Setiap orang berhak atas semua hak dan kebebasan-kebebasan yang tercantum dalam deklarasi ini dengan tidak ada perkecualian apa pun, seperti misalnya bangsa, warna kulit, jenis kelamin, bahasa, agama, politik atau pendapat lain, asal-usul kebangsaan, kemasyarakatan, milik, kelahiran ataupun kedudukan lain". 32

Untuk korban kekerasan atau korban tindak pidana selalu mengalami kritikan yang dilontarkan, karena terlalu banyaknya instrumen HAM yang memfokuskan pada perlindungan pelaku tindak pidana seperti yang tercantum dalam UDHR 1948 dan ICCPR 1966 mengenai "hak untuk hidup dan bebas dari penyiksaan atau tidakan atau pemidanaan yang kejam, tidak manusiawi atau merendahkan yang lain". Sedangkan perhatian kepada korban yang seharusnya dilakukan atas dasar belas kasihan dan hormat atas martabat korban (compassion and respect for their dignity) seolah-olah dilupakan, atau paling tidak kurang diperhatikan.

Pada tahun 1985 melalui Declaration of Basic Princsiples of Justice for Victims of Crime and Abuse of Power, perhatian PBB mulai meningkat khususnya yang berkaitan dengan akses untuk memperoleh keadilan, hak untuk memperoleh kompensasi, restitusi dan bantuan-bantuan lain yang harus diatur dalam UU Nasional. Bahkan kompensasi tersebut juga berlaku bagi keluarganya, khususnya yang hidupnya tergantung pada korban yang mati atau cacat; termasuk di sini korban Penyalahgunaan Kekuasaan (Victims of Abuse of Power).

Korban (victims) adalah orang-orang yang baik secara individual maupun kolektif telah menderita kerugian, termasuk kerugian fisik ataupun mental, emosional, ekonomi atau gangguan substansial fisik ataupun mental, emosional, ekonomi atau gangguan substansial terhadap hak-haknya yang fundamental, melalui perbuatan atau omisi yang melanggar hukum pidana di masing-masing negaratau omisi yang melanggar hukum pidana di masing-masing negara, termasuk penyalahgunaan kekuasaan. Dokumen internasional terkait yang lain adalah "UN Resolution on Protection of the Human Rights of Victims of Crime and Abuse of Power" pada Tahun 1990. ${ }^{33}$

Pihak yang paling dominan mengalami kekerasan adalah pihak wanita, sehingga PBB pada Tahun 1989 merekomendasikan komite penghapusan diskriminasi terhadap perempuan, dan Negara harus memasukkan dalam laporan-laporan informasi mengenai kekerasan dan langkah-langkah tindak untuk menanggulanginya.

Pada sidang ke-10 tahun 1991, diputuskan untuk mengalokasikan bagian dari sidang ke-10 untuk suatu diskusi dan kajian pasal 6 dan pasal-pasal lainnya dari konvensi tersebut yang ada hubungannya dengan kekerasan terhadap perempuan, pelecehan seksual dan eksploitasi terhadap perempuan. Pokok masalah tersebut dipilih untuk mengantisipasi diselenggarakannya konferensi Dunia tentang Hak Azasi Manusia Tahun

\footnotetext{
${ }^{32}$ Mohammad Monib dan Islah Bahrawi, Islam dan Hak Asasi Manusia Dalam Pandangan Nurcholish Madjid, (Jakarta: PT. Gramedia, 2011), hlm. 111 dan 202

${ }^{33}$ Muladi (Ed), Hak Asasi Manusia: Hakekat, Konsep dan Implikasinya dalam Perspektif Hukum dan Masyarakat, Cet. III, (Bandung: PT. Refika Aditama, 2009), hlm. 107-108
} 
1993, sebagai hasil Sidang Umum PBB dengan Resolusi No. 45/155, 18 Desember $1990 . .^{34}$

Terjadinya kekerasan kepada perempuan dengan mengabaikan hak asasi manusia dan kebutuhan pokok, yang seharusnya dilindungi oleh negara terutama dalam aspek legalitas terhadap gender. Dan ini terjadi karena ketimpangan laki-laki dan perempuan dalam hal kekuasaan, justru dampak yang terjadi akan menghambat kemajuan-kemajuan bagi para perempuan terkait pembangunan negara. Dan ini merupakan masalah yang krusial dalam hal sosial, maka negara harus segera memberikan solusi alternatif demi kepentingan pembangunan dalam hal kejahteraan sosial dengan tidak mengabaikan hakhak perempuan maupun hak-hak minoritas, karena bagaiamanapun merekalah pihak yang rentan terjadi korban kekerasan.

Dengan memperhatikan itu, resolusi Dewan Ekonomi dan Sosial Tanggal 24 Mei 1990 dalam annex, yang menyatakan bahwa kekerasan terhadap perempuan dalam keluarga dan masyarakat telah terjadi diberbagai lapisan masyarakat secara lintas kelas, kebudayaan, tingkat penghasilan, dan harus diatasi dengan segera dan efektif untuk menghapuskannya. Maka resolusi Dewan Ekonomi dan Sosial 1991/81 Tanggal 30 Mei 1991, di mana dewa merekomendasikan kerangka kerja bagi suatu perangkat internasional yang akan merumuskan secara eksplisit masalah kekerasan terhadap perempuan. $^{35}$

\section{Tinjauan Ham Internasional Terhadap Implementasi Ganti Rugi Bagi K orban Pemerkosaan Di M ahkamah Syar'iyah K ota L angsa}

Berdasakan hasil putusan Nomor 05/JN/2016/MS.Lgs mengenai jarimah pemerkosaan hukuman yang dijatuhakan kepada pelaku berupa:

1. Pelaku pertama dijatuhakan hukuman berupa 16 (enam belas) tahun penjara

2. Pelaku kedua dijatuhkan hukuman berupa 15 tahun penjara.

Sedangkan untuk korban sendiri tanpa mendapatkan ganti rugi baik berupa restitusi maupun kompensasi. Karena bagaimanapun di dalam Qanun No. 6 Tahun 2014 Tentang Hukum Jinayat mengenai ganti rugi disebutkan dalam Pasal 51 yaitu adanya permintaan korban untuk menjatuhkan hukuman berupa restitusi kepada pelaku yang besarannya paling banyak 750 (tujuh ratus lima puluh) gram emas murni.

Menurut pengakuan wakil Mahkamah Syar'iyah Kota Langsa Bapak Mursyid Syah, sampai saat ini belum ada putusan dari Mahkamah Syar'iyah Aceh yang telah memutuskan diyat hukuman tambahan berupa ganti rugi baik berupa restitusi maupun kompensasi. Dan untuk putusan di Mahkamah Syar'iyah Kota Langsa yang terjadi pada Tahun 2016, tidak dituangkannya tuntutan oleh jaksa penuntut umum mengenai prihal tuntutan ganti rugi baik kepada pelaku maupun lembaga yang berwenang yang

\footnotetext{
${ }^{34}$ Kelompok Kerja Convention Watch, Hak Azasi Perempuan Instrumen Hukum untuk Mewujudkan Keadilan Gender, Edisi IV, (Jakarta: Yayasan Pustaka Obor Indonesia, 2012), hlm. 47-48

${ }^{35}$ Ibid, hlm. 156-157
} 
memberikan kompensasi kepada korban. Jika hakim memutuskan suatu perkara yang tidak tertuang dalam putusan maka akan dianggap sebagai ultra petita.

Mengenai lembaga yang berwenang untuk memberikan kompensai kepada korban jarimah jinayat Qanun Aceh No. 6 Tahun 2014 yaitu baitu mal kabupaten/kota, yang dana tersebut diperoleh dari dana diyat (denda) yang diputuskan oleh Mahkamah Syar'iyah kepada pelaku jarimah sebagaimana yang tertuang di dalam Qanun Aceh No. 10 Tahun 2007 Tentang Baitul Mal dalam Bab XI (Ketentuan Uqubat) dan Bab XII (Pelaksanaan Uqubat). Akan tetapi aturan-aturan yang mengatur mengenai penggunaan dana tersebut belum diatur secara jelas oleh baitul mal, khususnya pada tahun 2016 dimana Mahkamah Syar'iyah Kota Langsa menjatuhkan hukuman kepada pelaku jarimah pemerkosaan.

Dan untuk penggunaan anggaran diyat yang telah disetorkan oleh pelaku ke baitul mal diatur dalam Qanun Aceh No. 10 Tahun 2018 Tentang Baitul Mal yang tercantum dalam Bab Ketiga Tentang harta uqubat dalam Pasal 142 dan 143 yaitu: BUD Kabupaten/Kota menyimpan harta uqubat dalam rekening khusus harta uqubat. BMK menggunakan harta uqubat untuk membayar uang kompensasi berdasarkan keputusan mahkamah syar'iyah yang telah mempunyai kekuatan hukum tetap. Pada prinsipnya pembayaran kompensasi yang dilakukan oleh lembaga berwenang adalah kejaksaaan sebagai eksekutor berdasarkan hasil putusan yang sudah inkrah dari peradilan.

Jika dilihat dari sisi HAM Internasional mengenai hasil putusan Mahkamah Syar'iyah Kota Langsa dalam memutuskan perkara jarimah pemerkosaan terutama terkait ganti-rugi bagi korban pemerkosaan, jelas bertentangan dengan HAM Internasional melalui deklarasi pada tahun 1985 di Milan berupa "Declaration of Basic Principles of J ustice for Victims of Crime and A buse of P ower" . PBB sendiri sangat memberi perhatian khusus terutama terhadap korban tindak pidana, karena bagaimanapun aspek yang paling dirugikan dalam tindak pidana adalah korban maupun keluarga korban, jika si korban merupakan tulang punggung keluarga. Di dalam deklarasi ini, PBB menginginkan adanya aspek keadilan yang diterima korban tindak pidana, yaitu hak untuk memperoleh kompensasi, restitusi dan bantuan-bantuan lain yang diatur di dalam perundang-undangan Nasional.

Akan tetapi di sisi yang lain, jika melihat aspek yuridis yang ada di dalam Qanun Aceh No. 6 Tahun 2014, telah berkesesuaian dengan HAM Internasional terkait dengan korban tindak pidana dalam hal memperoleh ganti rugi, sebagaimana yang tertuang di dalam Pasal 51 (1) yaitu adanya permintaan korban untuk menuntut uqubat restitusi paling banyak 750 (Tujuh Ratus Lima Puluh) gram emas murni, dan (2) menyebutkan hakim menetapkan besaran uqubat dengan mempertimbangkan keuangan terhukum.

Dan untuk kompensasi, perancang Qanun Aceh telah membuat terobosan terkait ganti rugi bagi korban jarimah jinayat, sebagaimana yang tertuang di dalam Qanun Aceh No. 10 Tahun 2018 Tentang Baitul Mal. Akan tetapi saat ini belum adanya kesinkronan program antara Mahkamah Syar'iyah dengan Baitul Mal Kota yaitu terkait aturan-aturan terperinci mengenai pelaksanaan pembayaran ganti rugi bagi korban jarimah jinayat, khususnya di kota Langsa.

Untuk perhatian terhadap korban tindak pidana, Qanun Jinayat Aceh telah melakukan terobosan baru, sementara perundang-udangan Nasional terkait ganti rugi bagi 
korban tindak pidana khususnya pemerkosaan belum diatur secara jelas baik berbentuk restitusi maupun kompensasi. Kalau pun ada restitusi, besaran maksimal hanyalah 2.5 Juta sebagaimana penyataan dari Ketua Pengadilan Negeri Kota Langsa dalam pembahasan di atas yaitu persepektif praktisi hukum terhadap ganti rugi bagi korban pemerkosaan dalam Qanun Aceh No. 6 Tahun 2014 . Sedangkan ganti rugi berbentuk kompensasi yang diberikan kepada korban, hanyalah korban pelanggaran HAM Berat melalui putusan pengadilan HAM, dan juga saksi Korban sebagaimana yang tertuang dalam PP No. 7 Tahun 2018 Tentang Pemberian Kompensasi, Restitusi, dan Bantuan Kepada Saksi Korban. Sementara korban tindak pidana, khususnya pemerkosaan tidak mendapatkan kompensasi, dan ini bertolak belakang dengan Deklaraasi Universal HAM PBB terutama dalam Pasal 3 "setiap orang berhak atas penghidupan, kemerdekaan dan keselamatan".

\section{Penutup}

\section{Kesimpulan}

Dalam Islam Pembayaran ganti-rugi bagi korban hudud diberikan kewenangan kepada lembaga keuangan kemasalahan umat Islam yaitu Baitul Mal sebagaimana yang pernah diimplementasikan oleh Khalifah Umar bin Khattab

Dalam Qanun Aceh No. 6 Tahun 2014 Tentang Hukum Jinayat tertuang mengenai ganti rugi bagi korban pemerkosaan pada pasal 51. Mengenai tinjauan HAM Internasional terhadap ganti-rugi bagi korban pemerkosaan dalam Qanun Aceh No. 6 Tahun 2014 telah sesuai dan berintegrasi dengan deklarasi HAM Internasional yaitu "Declaration of Basic Principles of Justice for Victims of Crime and Abuse of Power" di Milan Pada Tahun 1985.

\section{Saran-saran}

Untuk lembaga Keuangan kemasalahan umat Islam yaitu Baitul Mal Aceh agar lebih sistematik dalam penyusunan aturan-aturan pembayaran ganti-rugi terutama terkait dengan Juklak Peraturan Walikota Langsa mengenai mekanisme-mekanisme penggunaan biaya jarimah hudud yang terdapat dalam kas baitul mal Kota Langsa.

Agar Mahkamah Syar'iyyah Kota Langsa dalam memutuskan suatu perkara lebih memperioritaskan hukuman berbentuk denda dalam jarimah-jarimah tertentu untuk mendukung aturan baitul mal terkait dengan dana jarimah hudud yang akan dibayarkan kepada korban jarimah hudud khususunya korban pemerkosaan. Untuk aturan Negara agar melihat bahwa korban pemerkosaan termasuk pada aspek kejahatan yang telah melanggar Hak Asasi Manusia, terkait aturan ganti-rugi bagi korban pemerkosaan, negara bisa mengikuti kemajuan-kemajuan hukum yang ada di Aceh terutama terkait besaran dana ganti-rugi bagi korban pemerkosaan yang sepadan dalam mengobati pskologis yang dialami korban, dana kompensasi bersumber dari pelaku tindak pidana yang diputuskan oleh Pengadilan. 


\section{Daftar Pustaka}

Abdul Qadir Audah, al-Taysri' al-Jina'I al-Islami, Juz II hal. 365, Wahbah Zuhaili, alFiqh al-Islami wa Adillatuhu, Juz VII.

Abdur Rahman al-Jaziri, Kitabul Ala Madzahibul Arba'ah, Juz II, Beirut: tt,

Abdurrahman al-Jazaziri, Kitab al-Fiqh 'ala Mazhahib al-Arba'ah, Juz V, Beirut: Dar alFikr, tt,

al-Jazaziri, Abdurrahman., Kitab al-Fiqh 'ala Mazhahib al-Arba'ah, Juz V, Beirut: Dar al-Fikr, tt)

Ash-Shalabi, The Great Leader of Umar bin Khattab, terj. Khoirul Amru Harahap dan Akhmad Faozan, Jakarta: Pustaka al-Kautsar, 2008

Dinas Syariat Islam Aceh, Hukum Jinayat dan Hukum Acara Jinayat, Banda Aceh: Naskah Aceh, 2015

Faturochman, Ekandari Sulistyaningsihlm. , Dampak Sosial Psikologis Perkosaan, Buletin Psikologi, Tahun X, No. 1, Juni 2002

Fazlur Rahman, Doktrin Ekonomi Islam, dengan judul asli "Economic Doctrines of Islam”, Jilid I, Yogyakarta: PT. Dana Bhakti Wakaf, 1995

${ }^{1}$ Ibid, hlm. 142

Jaribah al-Haritsi, Fikih Ekonomi Umar ibnu al-Khattab, terj. Asmuni Sholihin Zamakhsyari, Jakarta: Khalifa Grup Pustaka al-Kaustar, 2010

Kelompok Kerja Convention Watch, Hak Azasi Perempuan Instrumen Hukum untuk Mewujudkan Keadilan Gender, Edisi IV, Jakarta: Yayasan Pustaka Obor Indonesia, 2012

Maizul Imran, Qiyas dan Analogi Hukum (Suatu Telaah dan Perbandingan dalam Penemuan Hukum), Alhurriyah: Jurnal Hukum Islam, Vol. 02 No. 01 Edisi Januari-Juni, 2017

Majda El-Muhtaj, Hak Asasi Manusia dalam Konstitusi Indonesia: Dari UUD 1945 Sampai Dengan Amendemen UUD 1945 Tahun 2002, Cet. II, Jakarta: Kencana, 2007

Mohammad Monib dan Islah Bahrawi, Islam dan Hak Asasi Manusia Dalam Pandangan Nurcholish Madjid, Jakarta: PT. Gramedia, 2011

Muladi (Ed), Hak Asasi Manusia: Hakekat, Konsep dan Implikasinya dalam Perspektif Hukum dan Masyarakat, Cet. III, (Bandung: PT. Refika Aditama, 2009

Muladi, Hak Asasi Manusia: Hakekat, Konsep dan Implikasinya dalam Perspektif Hukum dan Masyarakat, Cet. III, Bandung: PT. Refika Aditama, 2009

Muslich, Ahamd Wardi., Pangantar dan Asas Hukum Pidana Islam, (Jakarta: Sinar Grafika , 2006)

Neng Djubaedah, Pornografi dan Pornoaksi Ditinjau dari Hukum Islam, Jakarta, Kencana 2009

Sayyid Sabiq, Ringkasan Fiqh Sunnah,Beirut: Beirut Publishing, tt 
Volume 15, Nomor 1, Januari-Juni 2020

Wilyono R., Pengadilan Hak Asasi Manusia di Indonesia, Cet. III, Jakarta: Kencana, 2015

Zaki Ulya, Dinamika Penerapan Hukum Jinayat Sebagai Wujud Rekonstruksi Syari'at Islam Di Aceh, Jurnal Rechtsvinding, Vol. 5 No. 1, 2016

Zulkarnain Lubis dan Bakti Ritonga, Dasar-Dasar Hukum Acara Jinayah, Edisi I, Jakarta: Prenadamedia Group, 2016 